\title{
Prevalence, correlates and impact of pain and cramps in anti-MAG neuropathy: a multicentre European study
}

\author{
Yusuf A. Rajabally, ${ }^{1,2}$ \\ Emilien Delmont, ${ }^{3}$ \\ Fu Liong Hiew, ${ }^{2}$ \\ Anne-Catherine Aubé-Nathier, ${ }^{4}$ \\ Aude-Marie Grapperon, ${ }^{3} \quad$ Julien Cassereau, ${ }^{4}$ \\ Shahram Attarian. ${ }^{3}$
}

1. School of Life and Health Sciences, Aston Brain Centre, Aston University, Birmingham, U.K.

2. Regional Neuromuscular Clinic, Queen Elizabeth Hospital, University Hospitals of Birmingham, Birmingham, U.K.

3. Reference Centre for Neuromuscular Diseases and ALS, Centre Hospitalier Universitaire La Timone, 264 rue Saint-Pierre, 13385, Marseille, France.

4. Centre de Référence Maladies Neuromusculaires de l'Enfant et de l'Adulte Nantes-Angers, Centre Hospitalier Universitaire d'Angers, Angers, France.

Running title : Pain and cramps in anti-MAG neuropathy

Funding: None

Conflicts of Interest: None in relation to this work.

This article has been accepted for publication and undergone full peer review but has not been through the copyediting, typesetting, pagination and proofreading process, which may lead to differences between this version and the Version of Record. Please cite this article as doi: 10.1111/ene.13459

This article is protected by copyright. All rights reserved. 
Key Words: cramps, anti-MAG, function, neuropathy, pain, quality of life

Abbreviations: anti-MAG: anti myelin-associated glycoprotein; FSS: Fatigue Severity Score;

INCATSSS: Inflammatory Neuropathy Cause and Treatment Sensory Sum Score;

I-RODS : Inflammatory Rasch-Built Overall Disability Scale; MOSS: Medical Outcome Study-Social Support Survey; NPSI: Neuropathic Pain Symptom Inventory; ONLS: Overall Neuropathy Limitation Score; SF-36 HR-QoL: SF-36 health-related quality of life;

\title{
Correspondence to:
}

Yusuf A. Rajabally

School of Life and Health Sciences

Aston Brain Centre

Aston University

Birmingham B4 7ET

United Kingdom.

E-mail: y.rajabally@aston.ac.uk

\begin{abstract}
.
Background: The frequency of pain and cramps is uncertain in anti-MAG (Anti-myelin associated glycoprotein antibody) neuropathy. Whether these symptoms may affect function/quality of life is unknown.
\end{abstract}

Methods: We performed a cross-sectional study of the prevalence, correlates and impact of pain, pain subtypes and cramps, their severity, frequency and anatomical distribution, in 55 clinically stable patients with anti-MAG neuropathy.

Results: Pain of any type was reported by $80 \%$ of subjects. The most common subtype was paraesthesiae and dysaesthesiae (70\%). Cramps were reported by $>60 \%$ of patients, with lower limb cramps in all and upper limb cramps, in about $20 \%$. Cramps affected daily activities in $>30 \%$ of these

This article is protected by copyright. All rights reserved. 
subjects, sleep in $60 \%$, ability to exercise in $>30 \%$. Total Pain Score correlated with several SF-36 health-related quality of life (SF-36 HR-QoL) measures ( $<<0.05$ ), with Inflammatory Rasch-Built Overall Disability Scale (I-RODS) $(\mathrm{p}=0.006)$ and 10-metre timed walk $(\mathrm{p}=0.019)$. An independent association was ascertained with I-RODS ( $\mathrm{p}=0.002)$. Different pain subtypes showed multiple associations with SF-36 HRQoL measures and/or functional scales. Upper limb cramps had multiple SF-36 HRQoL/functional correlates, with an independent association with the Overall Neuropathy Limitation Score (ONLS) ( $\mathrm{p}=0.004)$. Cramp severity correlated with ONLS ( $\mathrm{p}=0.04)$ and I-RODS $(\mathrm{p}=0.028)$ and inversely with level of physiotherapy input ( $\mathrm{p}=0.009)$. Cramp frequency was associated with tremor score $(\mathrm{p}=0.004)$ and multiple SF-36 HRQoL subsections.

Conclusions: Neuropathic pain and cramps may affect function and quality of life in anti-MAG neuropathy. Optimizing treatments of these symptoms, including by adequate levels of physiotherapy, may be beneficial in affected patients and requires further research.

\section{Introduction.}

Anti-myelin associated glycoprotein antibody (Anti-MAG) neuropathy is a paraproteinaemic demyelinating neuropathy of usually slow progression resulting in disability through distal sensory more than motor deficits, as well as tremor. Neuropathic pain and cramps can be prominent and disabling [1-4]. We have previously described our findings of a study on the functional determinants of quality of life in this multicentre cohort [5]. This current analysis focused on the issue of pain and cramps in patients with anti-MAG neuropathy.

There are currently no effective, evidence-based immunotherapy treatments for anti-MAG neuropathy [6]. Immunoglobulins may have some short-term effect [6] but their appropriateness in this setting is highly questionable. In addition, following unconvincing initial results of a randomized controlled trial of Rituximab which had suggested a possible, albeit moderate, beneficial effect [7], a subsequent

This article is protected by copyright. All rights reserved. 
larger trial showed globally negative results [8]. Globally, a recent meta-analysis provides however globally, low-quality evidence for Rituximab and further longer-duration trials are needed [6].

Consideration of potential determinants of disability and quality of life is important in this medically currently untreatable disorder as may help shed light on potentially useful symptomatic therapies and ways of improving patients' daily lives.

The main objective of the current analysis was to evaluate the impact pain and its severity and quality, as well as of cramps, their severity, frequency and anatomical location, on neurological function and quality of life in patients with anti-MAG neuropathy.

\section{Patients and Methods.}

We performed a cross-sectional study of patients with a clinically, electrophysiologically and immunologically confirmed diagnosis of anti-MAG neuropathy, attending our respective neuromuscular clinics for their routine follow-up assessments, between March 2015 and February 2016. Inclusion criteria were (i) mainly distal sensory-predominant neuropathy (ii) presence of an IgM monoclonal protein (iii) presence of anti-MAG antibodies >1500 BTU [9] (iv) distal predominant demyelinating physiology ( $v$ ) clinically stable for 3 months at time of assessment. Patients were evaluated irrespective of previous immunomodulatory therapies received and of current or previous treatments for pain and cramps.

Pain was evaluated by a validated Pain Questionnaire, the NPSI (Neuropathic Pain Symptom Inventory) [10]. The questionnaire is detailed in its English language version, in Table 1 (Online Supplementary Material). The Total Pain Score was the sum of the intensity scores for the different pain subtypes. We also established, for each subject, [10], pain sub-scores.

This article is protected by copyright. All rights reserved. 
Cramps were evaluated by a validated questionnaire [11]. This questionnaire is detailed in its English language version in Table 2. (Online Supplementary Material) and ascertained severity, frequency and precise anatomical location of cramps.

All participants received a clinical assessment as part of their routine evaluation with: 80-point Medical Research Council (MRC) sum scores, Inflammatory Neuropathy Cause and Treatment (INCAT) Sensory Sum Score (INCATSSS) [12], Jamar grip dynamometry for dominant and nondominant hands, Overall Neuropathy Limitation Score (ONLS) [13], Inflammatory Rasch-built Overall Disability Score (I-RODS) [14], 10-metre timed walk, ataxia score [8], Whiget tremor score [15]. Health-related Quality of Life (HR-QoL) was ascertained by an interviewer-administered SF-36 Questionnaire [16] and fatigue by the Fatigue Severity Scale (FSS) [17]. Social support was determined by a modified abbreviated version of the Medical Outcome Study-Social Support Survey (MOSS) [18]. Level of physiotherapy input determined by a questionnaire, based on current recommendations for access to therapy in the U.K. [19]. This is detailed in Table 3 (Online Supplementary Material).

No further evaluations were performed. Patients did not undergo any additional electrophysiological tests, further blood tests, imaging or cerebrospinal fluid examinations for the current analysis. Biological and electrophysiological data were obtained from available records.

The SF-36 HRQoL Questionnaire was individually categorized before data analysis, as previously established, in different domains, consisting of "Physical Function" (PF), "Role Physical (RP), "Bodily Pain" (BP), “General Health" (GH), "Vitality" (VT), "Social Functioning” (SF), “Role Emotional” (RE), "Mental Health", "Physical Component Score" (PCS) and "Mental Component Score" (MCS). Intercorrelations were ascertained and independent associations were sought.

This article is protected by copyright. All rights reserved. 
This work was approved and registered by our relevant respective institutional review boards. All patients provided informed written consent. Statistical analyses were performed using SPSS 23.0 software (SPSS Inc., Chicago, IL, USA). Correlations were determined by using Spearman's 2-tailed correlation. As this study was exploratory, correction for multiple testing was not performed. Multivariate logistic regression was used to determine eventual independent associations. P values $<0.05$ were considered as significant.

\section{Results.}

We recruited 55 patients ( 32 from Marseille, France, 7 from Angers, France, and 16 from Birmingham, U.K.). There were 38 males and 17 females. Mean age was 71.5 years (S.D.: 10.3). Mean disease duration was 7.4 years (S.D.: 5.9). Mean anti-MAG antibody titer was 43813 BTU (S.D.: 26827.5).

There were no significant differences between the French and U.K. cohorts in terms of general prevalence and/or severity of pain $(p=0.55)$, and cramps $(p=0.54)$, gender distribution $(p=0.14)$, age $(p=0.62)$ or disease duration $(p=0.23)$. All physical assessments, including MRC sum score $(p=0.87)$, Jamar grip dynamometry $(p=0.54)$, ONLS $(p=0.11)$, I-RODS $(p=0.66)$, INCATSSS $(p=0.60), 10$-meter timed walk $(p=0.46)$, ataxia score $(p=0.65)$, tremor score $(p=0.25)$, Fatigue Severity Score $(p=0.86)$, were comparable in the French and U.K. cohorts.

Prevalence of evaluated symptoms are described in Table A. Most patients had a chronic sensory neuropathy with sensory ataxia $(34 / 55,62 \%)$ and upper limb tremor $(27 / 55,49 \%)$. Pain of any type was described by $44 / 55$ patients (80\%). Burning superficial spontaneous pain was reported by $21 / 55$ (38.2\%), pressing deep spontaneous pain by 19/55 (34.5\%), paroxysmal pain by $27 / 55$ (49.1\%), evoked pain by $28 / 55$ (50.1\%) and paraesthesiae/dysaesthesiae by $39 / 55$ (70.1\%). Cramps were This article is protected by copyright. All rights reserved. 
reported by $35 / 55$ (63.6\%). Upper limb cramps were present in only 10 of these 35 patients with cramps (28.6\%) whereas lower limb cramps were described by all 35 . Cramps affected daily activities in $11 / 35$ (31.4\%) of these subjects, sleep in $21 / 35$ (60\%), ability to exercise in $11 / 35(31.4 \%)$ and the patient perception of quality of life in $12 / 35$ (34.3\%).

Main results of correlation analyses showed multiple positive associations of pain severity and quality of life and disability. These are detailed in Table B.

Total Pain Score correlated with several SF-36 HR-QoL measures $(p<0.05)$ (see Table B.), with I-RODS $(p=0.006)$ and 10-metre timed walk $(p=0.019)$. The Total Pain Score was independently associated with BP $(p<0.001)$. Considering only the functional parameters, an independent association was found with the I-RODS $(p=0.002)$.

Burning superficial spontaneous pain was independently associated with the INCATSSS $(p=0.004)$ and modified MOSS ( $p=0.008)$.

Paroxysmal pain was independently associated with PCS $(p=0.007)$. Amongst the functional parameters, an independent association was found with ataxia score $(p=0.007)$.

Paraesthesiae/dysaesthesiae were independently associated with BP $(p=0.004)$. Considering non-HRQoL parameters, an independent association was found with mean FSS ( $p=0.029)$.

Main correlation results of the cramp characteristics are summarized in Table C. Again, multiple positive associations were ascertained between cramp location, severity and frequency and quality of life and function. Lower limb cramps correlated with ataxia score only, amongst all studied functional parameters $(p=0.034)$.

This article is protected by copyright. All rights reserved. 
Upper limb cramps were independently associated with PF ( $p=0.011)$. An independent association was found with the ONLS $(p=0.004)$. More precise cramp location was relevant to performance and function as hand cramps were independently associated with ONLS ( $p=0.015)$. Cramp frequency was independently associated with RE $(p=0.031)$ and $B P(p=0.031)$.

Patients describing interference of cramps with their daily activities were significantly more likely to have a lower MRCSS $(p=0.045)$, worse arm ONLS score $(p=0.003)$ and total ONLS score $(p=0.009)$, lower I-RODS $(p=0.035)$, higher INCATSSS $(p=0.038)$ and higher tremor score $(p=0.027)$. Patients who felt cramps interfered with their ability to exercise were more likely to have lower arm ONLS scores $(p=0.016)$. Those who described a perceived impact of their cramps on their global quality of life were similarly more likely to have lower ONLS arm scores $(p=0.018)$, but also more severe ataxia $(p=0.031)$, although SF-36 parameters failed to be influenced.

The level of physiotherapy input correlated with the Total Pain Score $(p=0.024)$. Also, level of physiotherapy input was associated the presence of cramps $(p=0.04)$. However, conversely and remarkably, cramp severity was strongly inversely associated with the level of physiotherapy input $(p=0.009)$. Similarly, an independent negative association was found between level of physiotherapy input and cramps interfering with sleep $(p=0.011)$.

The level of social support (modified MOSS) was associated with the presence of burning pain $(p=0.024)$, but not with any other pain or cramp characteristics or features.

This article is protected by copyright. All rights reserved. 


\section{Discussion.}

Our multicentre analysis of 55 patients firstly indicates that both pain and cramps are common features that may significantly impact upon HR-QoL, as well on function in patients with anti-MAG neuropathy. Importantly, both may be more frequent with longer disease duration, indicating the importance and relevance of regular re-assessments.

The frequency of pain was high, occurring in $80 \%$ of our cohort. Paraesthesiae and dysaesthesiae, although often considered as non-painful symptoms by patients and physicians, were present in $>70 \%$. Consideration of pain management, appears therefore highly relevant in anti-MAG neuropathy, as has been found previously in relation to quality of life more generally in neuropathy [20]. Similarly, we found comparable findings about cramps in our cohort. Although cramps were reported by $63.6 \%$ of patients, they affected mostly the lower limbs, with $<20 \%$ describing upper limb involvement. Hand cramps appeared however the most relevant to disability with an independent association with the ONLS. Interestingly, whereas cramp severity was associated with neurological disability, cramp frequency on the other hand was related to HR-QoL measures, with independent associations with RE and BP. This is in keeping with previous findings in genetic neuropathy [11].

We found that presence of cramps was associated with higher levels of physiotherapy input. This may be intuitively expected as probably relates to the naturally higher likelihood of referrals of more affected subjects. However, the concomitant finding of worst cramps in patients with the lowest physiotherapy input may suggest a favorable effect of physiotherapy on cramp severity. We in addition, found that cramps interfering with sleep also inversely correlated with level of physiotherapy. This is in keeping with some recent literature [21], although the benefit of nonmedical interventions for cramps is, to our knowledge, not established from meta-analyses performed to date [22].

This article is protected by copyright. All rights reserved. 
HR-QoL measures represent the markers that ultimately need to be positively influenced by treatment interventions for meaningful benefit to patients [23]. Pain can be a prominent although under-recognized feature of inflammatory neuropathy [24, 25], and anti-MAG neuropathy may be a likelier cause of pain amongst immune-mediated neuropathies [24]. In that study, positive sensory symptoms of paraesthesiae and dysesthesiae were commonest. Our current results appear confirmatory of these findings and in agreement with the conclusions of that previous study that these are symptoms often not considered as pain in the clinical setting.

We did not evaluate the effects of previous immunotherapy or of medical treatments for pain and cramps in our cohort. This was because our aim was to cross-sectionally ascertain occurrence and correlates of these symptoms rather than retrospectively attempt to determine drug effects. We otherwise did not here specifically consider co-morbidities which may have resulted in arthritic or musculo-skeletal pains and this represents a limitation of our study.

Only properly designed therapeutic drug trials may in future answer the question regarding the eventual efficacy of pain and cramp treatment on function and quality of life in anti-MAG neuropathy. The benefits of physiotherapy input optimization are possible, this despite the crosssectional and non-controlled nature of our analysis. The scale we used to determine level of physiotherapy input is clearly limited as does not consider intensity of sessions or differences of practice between physiotherapists and institutions, which limits the value of the findings. However, benefit of physiotherapy in anti-MAG neuropathy may merit further study in the setting of an adequate randomized controlled interventional trial. As demonstrated in other neuromuscular disorders, favorable effects of non-drug interventions such as aerobic exercise training and cognitive behavioral therapy may be obtained and objectively measurable [26].

This article is protected by copyright. All rights reserved. 
In conclusion, we believe our study brings new insight on practical management of patients with anti-MAG neuropathy, in indicating that pain and cramp severity, frequency, quality and distribution can play a significant part in the impairment of function and quality of life in affected patients. This is important in a disorder for which effective evidence-based treatments remain unavailable. Future research may need to focus on these associated secondary, to date still poorly-recognized symptoms of anti-MAG neuropathy, both in terms of therapeutic benefit of evaluated drugs and other interventions, as well as, eventually, consideration of these manifestations per se, as primary therapeutic targets.

Table A. Prevalence of evaluated symptoms in 55 patients with anti-MAG neuropathy.

\begin{tabular}{|c|c|c|}
\hline Symptom & $\begin{array}{l}\text { Prevalence in } \\
\text { cohort }\end{array}$ & Percentage \\
\hline Sensory Ataxia & $34 / 55$ & $62 \%$ \\
\hline Upper Limb Tremor & $27 / 55$ & $49.1 \%$ \\
\hline Pain of any type & $44 / 55$ & $80 \%$ \\
\hline $\begin{array}{l}\text { Burning superficial } \\
\text { spontaneous pain }\end{array}$ & $19 / 55$ & $34.5 \%$ \\
\hline Paroxysmal pain & $27 / 55$ & $49.1 \%$ \\
\hline Evoked pain & $28 / 55$ & $50.1 \%$ \\
\hline $\begin{array}{l}\text { Paraesthesiae, } \\
\text { Dysaesthesiae }\end{array}$ & $39 / 55$ & $70.1 \%$ \\
\hline Cramps & $35 / 55$ & $63.6 \%$ \\
\hline Upper Limb cramps & $10 / 55$ & $18.2 \%$ \\
\hline Lower Limb cramps & $35 / 55$ & $63.6 \%$ \\
\hline $\begin{array}{l}\text { Cramps affecting } \\
\text { daily activities }\end{array}$ & $11 / 55$ & $20 \%$ \\
\hline $\begin{array}{l}\text { Cramps affecting } \\
\text { sleep }\end{array}$ & $21 / 55$ & $38.2 \%$ \\
\hline $\begin{array}{l}\text { Cramps affecting } \\
\text { ability to exercise }\end{array}$ & $11 / 55$ & $20 \%$ \\
\hline $\begin{array}{l}\text { Cramps affecting } \\
\text { patient perception of } \\
\text { quality of life }\end{array}$ & $12 / 55$ & $21.8 \%$ \\
\hline
\end{tabular}

Table B. Correlates of Pain (Total Pain

This article is protected by copyright. All rights reserved. 
Score and Pain Quality) with functional and Health-Related Quality of Life Parameters in $\mathbf{5 5}$ patients with anti-MAG neuropathy.

\begin{tabular}{|c|c|c|c|c|c|}
\hline & $\begin{array}{l}\text { NPSI Total Pain } \\
\text { Score }\end{array}$ & Burning Pain & Pressing Pain & $\begin{array}{l}\text { Paroxysmal } \\
\text { Pain }\end{array}$ & $\begin{array}{l}\text { Paraesthesiae/ } \\
\text { Dysaethesiae }\end{array}$ \\
\hline $\begin{array}{l}\text { Disease. } \\
\text { duration }\end{array}$ & NS & $\begin{array}{c}\text { Rho:0.438 } \\
P=0.047\end{array}$ & NS & NS & NS \\
\hline $\begin{array}{l}\text { MRC sum } \\
\text { score }\end{array}$ & NS & NS & NS & NS & NS \\
\hline $\begin{array}{l}\text { Dominant } \\
\text { Grip }\end{array}$ & NS & NS & NS & NS & NS \\
\hline ONLS Total & NS & NS & NS & $\begin{array}{l}\text { Rho:0.527; } \\
P=0.005\end{array}$ & NS \\
\hline I-RODS & $\begin{array}{c}\text { Rho=-0.409; } \\
\text { P }=0.006\end{array}$ & NS & NS & $\begin{array}{c}\text { Rho:-0.435; } \\
\quad P=0.023\end{array}$ & $\begin{array}{c}\text { Rho:-0.313; } \\
\text { P=0.049 }\end{array}$ \\
\hline $\begin{array}{l}\text { INCAT } \\
\text { sensory sum } \\
\text { score }\end{array}$ & NS & $\begin{array}{c}\text { Rho: } 0.469 \\
P=0.037\end{array}$ & NS & $\begin{array}{l}\text { Rho:0.447; } \\
P=0.025\end{array}$ & NS \\
\hline Ataxia score & NS & NS & NS & $\begin{array}{l}\text { Rho:0.461; } \\
\quad P=0.015\end{array}$ & NS \\
\hline $\begin{array}{l}\text { Whiget } \\
\text { Tremor } \\
\text { score }\end{array}$ & NS & NS & NS & NS & NS \\
\hline $\begin{array}{l}\text { Ten meter } \\
\text { walk }\end{array}$ & $\begin{array}{c}\text { Rho:0.425; } \\
P=0.019\end{array}$ & NS & NS & $\begin{array}{c}\text { Rho:0.755; } \\
P<0.001\end{array}$ & NS \\
\hline $\begin{array}{l}\text { Modified } \\
\text { Moss }\end{array}$ & NS & $\begin{array}{l}\text { Rho: } 0.491 \\
P=0.024\end{array}$ & NS & NS & NS \\
\hline $\begin{array}{l}\text { Fatigue } \\
\text { Severity } \\
\text { Scale (mean } \\
\text { score) }\end{array}$ & $\begin{array}{l}\text { Rho: } 0.360 ; \\
P=0.018\end{array}$ & NS & $\begin{array}{c}\text { Rho:0.467; } \\
\text { P=0.044 }\end{array}$ & $\begin{array}{c}\text { Rho:0.444; } \\
P=0.020\end{array}$ & $\begin{array}{c}\text { Rho:0.376; } \\
P=0.017\end{array}$ \\
\hline PF & NS & NS & NS & $\begin{array}{c}\text { Rho:-0.417; } \\
\quad P=0.03\end{array}$ & NS \\
\hline $\mathbf{R P}$ & NS & NS & NS & NS & NS \\
\hline BP & $\begin{array}{c}\text { Rho:-0.661; } \\
\text { P<0.001 }\end{array}$ & NS & $\begin{array}{c}\text { Rho:-0.678; } \\
\quad P=0.001\end{array}$ & NS & $\begin{array}{l}\text { Rho:-0.454; } \\
\text { P=0.003 }\end{array}$ \\
\hline GH & $\begin{array}{c}\text { Rho }=-0.366 \\
P=0.014\end{array}$ & NS & NS & $\begin{array}{c}\text { Rho:-0.386; } \\
P=0.047\end{array}$ & $\begin{array}{l}\text { Rho:-405; } \\
P=0.010\end{array}$ \\
\hline VT & $\begin{array}{c}\text { Rho }=-0.307 ; \\
P=0.043\end{array}$ & NS & NS & NS & NS \\
\hline SF & NS & NS & NS & NS & NS \\
\hline RE & NS & NS & NS & NS & NS \\
\hline MH & $\begin{array}{c}\text { Rho }=-0.316 \\
P=0.037\end{array}$ & NS & NS & NS & $\begin{array}{c}\text { Rho:-0.391; } \\
\quad P=0.013\end{array}$ \\
\hline PCS & $\begin{aligned} \text { Rho } & =-0.432 ; \\
P & =0.003\end{aligned}$ & NS & NS & $\begin{array}{c}\text { Rho:-0.520; } \\
P=0.005\end{array}$ & NS \\
\hline MCS & NS & NS & NS & NS & NS \\
\hline
\end{tabular}

This article is protected by copyright. All rights reserved. 
Table C. Correlates of various cramp characteristics with functional and Health-Related Quality of Life Parameters in 55 patients with anti-MAG neuropathy.

\begin{tabular}{|c|c|c|c|c|c|c|c|}
\hline & $\begin{array}{l}\text { Presence of } \\
\text { Cramps }\end{array}$ & $\begin{array}{c}\text { Cramp } \\
\text { Frequency } \\
\text { (number of } \\
\text { days or nights } \\
\text { per week) }\end{array}$ & $\begin{array}{l}\text { Severity } \\
\text { Of Worst } \\
\text { Cramp }\end{array}$ & $\begin{array}{l}\text { Hand } \\
\text { Cramps }\end{array}$ & $\begin{array}{c}\text { Cramps } \\
\text { Interfering } \\
\text { With } \\
\text { Daily } \\
\text { Activities }\end{array}$ & $\begin{array}{c}\text { Cramps } \\
\text { Interferin } \\
\text { g with } \\
\text { Sleep }\end{array}$ & $\begin{array}{c}\text { Cramps } \\
\text { Interfering } \\
\text { with } \\
\text { Quality of } \\
\text { Life }\end{array}$ \\
\hline $\begin{array}{l}\text { Disease. } \\
\text { duration }\end{array}$ & $\begin{array}{r}\text { Rho: } 0.289 \\
P=0.034\end{array}$ & NS & NS & $\begin{array}{c}\text { Rho: } \\
0.367 \\
P=0.030\end{array}$ & NS & NS & NS \\
\hline MRC sum score & NS & NS & NS & $\begin{array}{c}\text { Rho }=-0.439 \\
P=0.008\end{array}$ & $\begin{array}{l}\text { Rho }=-0.41 \\
P=0.045\end{array}$ & NS & NS \\
\hline Dominant Grip & NS & NS & NS & $\begin{array}{c}\text { Rho }= \\
-0.447 \\
P=0.015\end{array}$ & NS & NS & NS \\
\hline ONLS Total & NS & NS & $\begin{array}{c}\text { Rho }=-0.360 \\
P=0.004\end{array}$ & $\begin{array}{l}\text { Rho:0.46 } \\
P=0.005\end{array}$ & $\begin{array}{c}\text { Rho: }-0.433 \\
P=0.009\end{array}$ & NS & NS \\
\hline I-RODS & NS & NS & $\begin{array}{c}\text { Rho }=0.383 \\
P=0.028\end{array}$ & $\begin{array}{c}\text { Rho: } \\
0.371 \\
P=0.028\end{array}$ & $\begin{array}{c}\text { Rho: }-0.357 \\
P=0.035\end{array}$ & NS & NS \\
\hline $\begin{array}{l}\text { INCAT sensory } \\
\text { sum score }\end{array}$ & NS & NS & NS & NS & $\begin{array}{c}\text { Rho:0.369 } \\
P=0.038\end{array}$ & NS & NS \\
\hline Ataxia score & $\begin{array}{l}\text { Rho: } 0.305 \\
P=0.028\end{array}$ & NS & NS & $\begin{array}{c}\text { Rho: } \\
0.398 \\
P=0.022\end{array}$ & NS & NS & $\begin{array}{l}\text { Rho:0.376 } \\
P=0.031\end{array}$ \\
\hline $\begin{array}{l}\text { Whiget Tremor } \\
\text { score }\end{array}$ & NS & $\begin{array}{l}\text { Rho:0.418; } \\
\text { P=0.024 }\end{array}$ & NS & NS & $\begin{array}{c}\text { Rho:0.386 } \\
P=0.027\end{array}$ & NS & NS \\
\hline $\begin{array}{l}\text { Ten meter } \\
\text { walk }\end{array}$ & NS & NS & NS & NS & NS & NS & NS \\
\hline $\begin{array}{l}\text { Modified } \\
\text { Moss }\end{array}$ & NS & NS & NS & NS & NS & NS & NS \\
\hline $\begin{array}{l}\text { Level of } \\
\text { Physiotherapy } \\
\text { Input }\end{array}$ & $\begin{array}{l}\text { Rho: } 0.28 \\
P=0.040\end{array}$ & NS & $\begin{array}{c}\text { Rho }=-0.449 \\
P=0.009\end{array}$ & NS & NS & $\begin{array}{l}\text { Rho: } \\
-0423\end{array}$ & NS \\
\hline
\end{tabular}

This article is protected by copyright. All rights reserved. 


\begin{tabular}{|c|c|c|c|c|c|c|c|}
\hline & & & & & & $\mathrm{P}=0.011$ & \\
\hline $\begin{array}{l}\text { Fatigue } \\
\text { Severity Scale } \\
\text { (mean score) }\end{array}$ & NS & $\begin{array}{c}\text { Rho: } 0.472 \\
P=0.007\end{array}$ & NS & NS & NS & NS & NS \\
\hline $\mathrm{PF}$ & NS & NS & NS & NS & $\begin{array}{l}\text { Rh:-0.457 } \\
P=0.006\end{array}$ & NS & NS \\
\hline RP & NS & $\begin{array}{l}\text { Rho:-0.55 } \\
\text { P=0.001 }\end{array}$ & NS & NS & $\begin{array}{l}\text { Rh:-0.4 } \\
P=0.017\end{array}$ & NS & NS \\
\hline BP & NS & $\begin{array}{c}\text { Rho: }-0.405 \\
P=0.024\end{array}$ & NS & NS & NS & NS & NS \\
\hline GH & NS & NS & NS & NS & $\begin{array}{l}\text { Rh:- } 0.353 \\
P=0.038\end{array}$ & NS & NS \\
\hline VT & NS & $\begin{array}{c}\text { Rho:-0.453 } \\
P=0.011\end{array}$ & NS & NS & $\begin{array}{c}\text { Rho:-0.372 } \\
P=0.038\end{array}$ & NS & NS \\
\hline SF & NS & $\begin{array}{c}\text { Rho:-0.614 } \\
\text { P }<0.001\end{array}$ & NS & NS & $\begin{array}{c}\text { Rho: }-0.486 \\
P=0.003\end{array}$ & NS & $\begin{array}{l}\text { Rho:- } 0.374 \\
P=0.027\end{array}$ \\
\hline RE & NS & $\begin{array}{c}\text { Rho: }-0.590 \\
P=0.001\end{array}$ & NS & NS & NS & NS & NS \\
\hline $\mathrm{MH}$ & NS & $\begin{array}{c}\text { Rho: }-0.511 \\
P=0.003\end{array}$ & NS & NS & NS & NS & NS \\
\hline PCS & NS & NS & NS & NS & $\begin{array}{c}\text { Rho:-0.566 } \\
\text { P }<0.001\end{array}$ & NS & NS \\
\hline MCS & NS & $\begin{array}{l}\text { Rho: }-0.564 \\
P=0.001\end{array}$ & NS & NS & NS & NS & NS \\
\hline
\end{tabular}

This article is protected by copyright. All rights reserved. 


\section{References.}

1.Nobile-Orazio E, Meucci N, Baldini L, Di Troia A, Scarlato G. Long-term prognosis of neuropathy associated with anti-MAG IgM M-proteins and its relationship to immune therapies. Brain 2000;123:710-7.

2. Ellie E, Vital A, Steck A, Boiron JM, Vital C, Julien, J. Neuropathy associated with "benign" antimyelin-associated glycoprotein IgM gammopathy: clinical, immunological, neurophysiological pathological findings and response to treatment in 33 cases. J Neurol 1996;243:34-43.

3. Chassande B, Léger JM, Younes-Chennoufi AB, Bengoufa D, Maisonobe T, Bouche $P$ et al. Peripheral neuropathy associated with IgM monoclonal gammopathy: correlations between Mprotein antibody activity and clinical/electrophysiological features in 40 cases. Muscle Nerve, 1998; 21:55-62.

4. Launay M, Delmont E, Benaïm C, Sacconi S, Butori C, Desnuelle C. Les polyneuropathies avec IgM monoclonale anti-MAG : étude descriptive clinique, biologique, électrophysiologique et anatomopathologique d'une cohorte de 13 patients Rev Neurol (Paris) 2009;65:1071-79.

5. Delmont E, Hiew FL, Cassereau J, Aubé-Nathier AC, Grapperon AM, Attarian S, et al. Determinants of Health-Related Quality of life in anti-MAG neuropathy: a cross-sectional multicentre European study. J Peripher Nerv Syst 2017;22:27-33.

6. Lunn MP, Nobile-Orazio E. Immunotherapy for IgM anti-myelin-associated glycoprotein paraprotein-associated peripheral neuropathies. Cochrane Database Syst Rev. 2016 Oct 4;10:CD002827.

7. Dalakas MC, Rakocevic G, Salajegheh M, Dambrosia JM, Hahn A. F, et al. Placebo-controlled trial of rituximab in IgM anti-myelin-associated glycoprotein antibody demyelinating neuropathy. Ann Neurol 2009;65:286-293.

This article is protected by copyright. All rights reserved. 
8. Léger JM, Viala K, Nicolas G, Créange A, Vallat JM, Pouget J, et al. Placebo-controlled trial of rituximab in IgM anti-myelin-associated glycoprotein neuropathy. Neurology, 2013;80:2217-25.

9. Kuijf ML, Eurelings M, Tio-Gillen AP, van Doorn P, van den Berg LH, Hooijkaas H, et al. Detection of anti-MAG antibodies in polyneuropathy associated with IgM monoclonal gammopathy. Neurology 2009;73:688-95.

10. Bouhassira D, Attal N, Fermanian J, Alchaar H, Gautron M, Masquelier E, et al. Development and validation of the Neuropathic Pain Symptom Inventory. Pain 2004;108:248-57.

11. Johnson NE, Sowden J, Dilek N, Eichinger K, Burns J, Mcdermott MP, et al. Prospective study of muscle cramps in Charcot-Marie-Tooth disease. Muscle Nerve 2015;51:485-8.

12. Merkies IS, Schmitz PI, van der Meché FG, Samijn JP, van Doorn P. Clinimetric evaluation of a new overall disability scale in immune mediated polyneuropathies. J Neurol Neurosurg Psychiatry, 2002;72:596-601.

13. Graham RC, Hughes RA. A modified peripheral neuropathy scale: the Overall Neuropathy Limitations Scale. J Neurol Neurosurg Psychiatry 2006;77;973-6.

14. Draak TH, Vanhoutte EK, van Nes SI, Gorson KC, Van der Pol WL, Notermans NC, et al.; PeriNomS Study Group. Changing outcome in inflammatory neuropathies: Rasch-comparative responsiveness. Neurology 2014;83:2124-32.

15. Louis ED, Barnes L, Wendt KJ, Ford B, Sangiorgio M, Tabbal S, et al. A teaching videotape for the assessment of essential tremor. Mov Disord 2001;16:89-93.

16. Ware JE, Kosinski M. K. S. SF-36 Physical and Mental Health Summary Scales: A User'sManual, in Boston: New England Medical Center, The Health Institute, 1994.

This article is protected by copyright. All rights reserved. 
17. Krupp LB., LaRocca NG., Muir-Nash J, Steinberg AD. The fatigue severity scale. Application to patients with multiple sclerosis and systemic lupus erythematosus. Arch Neurol 1989;46:1121-23.

18. Sherbourne CD, Stewart AL. The MOS social support survey. Soc Sci Med 1991;32:705-14.

19. National Institute for Health and Care Excellence. Stroke Rehabilitation in Adults. June 2013. nice.org.uk/guidance/cg162

20. Maxwell SK, Barnett C, Kokoyi S, Leung JC, Yu JJ, Bril V, Katzberg HD. Association of social support with quality of life in patients with polyneuropathy J Peripher Nerv Syst 2013;18:37-43.

21. Hallegraeff JM, van der Schans CP, de Ruiter R, de Greef MH. Stretching before sleep reduces the frequency and severity of nocturnal leg cramps in older adults: a randomised trial. J Physiother $2012 ; 5817-22$

22. Blyton F, Chuter V, Walter KE, Burns J. Non-drug therapies for lower limb muscle cramps. Cochrane Database Syst Rev. 2012 Jan 18;1:CD008496.

23. Rajabally YA, Cavanna AE. Health-related quality of life in chronic inflammatory neuropathies: a systematic review. J Neurol Sci 2015;348:18-23.

24. Pazzaglia C, Briani C, Nobile-Orazio E, Caliandro P, Granata G, Tonali PA, et al. Occurrence and characterization of Pain in immune-mediated neuropathies: a multicentre prospective study. Eur J Neurol. 2011;18:177-83.

25. Rajabally YA, Chavada G. Lewis-Sumner syndrome of pure upper-limb onset: diagnostic, prognostic, and therapeutic features. Muscle Nerve 2009;39:206-20.

26. Janssen B, Voet N, Geurts A, van Engelen B, Heerschap A. Quantitative MRI reveals decelerated fatty infiltration in muscles of active FSHD patients. Neurology 2016;86:1700-1707.

This article is protected by copyright. All rights reserved. 